\title{
Identification of Nutrient Contents in Six Potential Green Biomasses for Developing Liquid Organic Fertilizer in Closed Agricultural Production System
}

\author{
Fahrurrozi $^{\# 1}$, Yenny Sariasih ${ }^{*}$, Zainal Muktamar ${ }^{\$}$, Nanik Setyowati ${ }^{\# 2}$, Mohammad Chozin ${ }^{\# 3}$, \\ Sigit Sudjatmiko ${ }^{\# 4}$ \\ \#Agronomy Department, Universitas Bengkulu, Bengkulu 38121, Indonesia \\ E-mail: ${ }^{1}$ fahrurrozi@unib.ac.id, ${ }^{2}$ setyowati280260@unib.ac.id, ${ }^{3}$ mchozin@unib.ac.id, ${ }^{4}$ sigitsudjatmiko@unib.ac.id \\ ${ }^{*}$ Crop Protecion Department, Universitas Bengkulu, Bengkulu 38121, Indonesia \\ E-mail:yennysariasih@unib.ac.id \\ ${ }^{\$}$ Soil Science Department, Universitas Bengkulu, Bengkulu 38121, Indonesia \\ E-mail:muktamar@unib.ac.id
}

\begin{abstract}
The use of solid organic fertilizer in closed agricultural production system must be combined with foliar application to improve fertilizing effectiveness. Nutrient contents in tissues of green biomass determine the quality of liquid organic fertilizer. Six potential green biomasses, Tithonia diversifolia (Hemsl.) A. Gray, Gliricidia sepium (Jacq.) Kunth ex Walp., Leucaena leucocephala (Lamk.) de Wit, Ageratum conyzoides L., Eichhornia crassipes (Mart.) Solms, and banana corms were identified its nutrient contents. Samples were dried at $60^{\circ} \mathrm{C}$ for 48 hours, grinded, analyzed for $\mathrm{N}, \mathrm{P}, \mathrm{K}, \mathrm{Ca}-\mathrm{ex}$, Mg-ex, C, cellulose and lignin contents. Results indicated that $\boldsymbol{T}$. diversifolia and $\boldsymbol{A}$. conyzoides had the highest $\mathbf{N}$ content compared to other biomasses. A. conyzoides had the highest $\mathbf{P}$ content, followed by $T$. diversifolia. A. conyzoides had the highest $\mathrm{K}$ content, followed by $\mathbf{G}$. sepium. The highest Ca-ex content was in L. leucocephala, followed by $A$. conyzoides. The highest Mgex content was found in A. conyzoides, followed by L. leucocephala. The highest $\mathrm{C}$ content was found in E.crassipes, followed by G. Sepium. T. diversifolia had the highest cellulose content, followed by E.crassipes. Lignin content of all biomasses was similar. Lastly, E.crassipes had the highest $\mathrm{C} / \mathrm{N}$ compared to other biomass, and both $T$. diversifolia and $A$. conyzoides had the lowest $\mathrm{C} / \mathrm{N}$. It is concluded that $A$. conyzoides is the most promising green biomass for production of liquid organic fertilizer, followed by $T$. diversifolia and $G$. sepium.
\end{abstract}

Keywords - liquid organic fertilizer; T. diversifolia; G. sepium; L. leucocephala; A. conyzoides; E. crassipes; banana corms

\section{INTRODUCTION}

Vegetable production in a closed agricultural production system is considered as organic vegetable production, a system approach where the production was intentionally designed to promote biodiversity, biological cycles, and soil biological activity [1]. The use of solid organic fertilizer has been widely practiced for nutrient supply in organic vegetable production. However, solid organic fertilizer takes a longer time to mineralize than crop life-cycles [2], [3]. This slow-release characteristic endorses the use of liquid organic fertilizer to fulfill nutrient required for organic crop production which might be effectively applied through leaves [4].
The use of liquid organic fertilizers has been widely practiced for organic vegetable production. Although some publications reported that effects of liquid organic fertilizer had been successfully improved growth and yield of many vegetables, such as in lettuce [5], green cabbage [6], cauliflower [7], kaelan [8], potato [9], tomato [10] and sweet-corn [11], the use of tithonia-enriched liquid organic fertilizer in organic vegetable production have been found to be less effective in promoting growth and yield of carrot [12] and sweet corn [13], [14]. Green biomass is one of the main components to determine the effectiveness of liquid organic fertilizer for vegetable production. Since the effectiveness of crop responses to liquid organic fertilizer is also determined by green biomass used to compose the liquid organic fertilizer [15], type of green biomass must be highly 
considered in the production of liquid organic fertilizer. The composition of raw materials affects the quality and stability of compost prepared [16]. Research by [17], [18], [19], [20] for example, used Tithonia diversifolia (Hamsley) A. Gray), known as wild Mexican flower, as a source of green biomass for liquid organic fertilizer used in organic vegetable production.

According to [15], organic vegetable production must be intentionally designed to promote biodiversity, biological cycles, and soil biological activities. The use local materials, therefore, is an essential part of organic vegetable production practices since there are specific spatial and temporal interactions between crops and soil during the course of crop development. The decomposition rates of the leaves were significantly correlated with the initial $\mathrm{N}$ and $\mathrm{Ca}$ concentrations in the leaves as well as with the initial $\mathrm{C}: \mathrm{N}$, $\mathrm{C}: \mathrm{P}$ and lignin: $\mathrm{N}$ ratios [21]. It is therefore very important to successfully benefit from crops grown in closed agriculture system that use liquid organic fertilizer by carefully selecting potential green biomass available around growing area selected as a source of nutrient for liquid organic fertilizer.

This experiment aimed to determine the nutrient contents of six green biomasses that will be potentially used for the production of liquid organic fertilizer.

\section{MATERIALS AND METHODS}

This experiment was conducted from April to July 2016, Six potential green biomasses (1) Tithonia diversifolia (Hemsl.) A. Gray, (2) Gliricidia sepium (Jacq.) Kunth ex Walp., (3) Leucaena leucocephala (Lamk.) de Wit, (4) Ageratum conyzoides L., (5) Eichhornia crassipes (Mart.) Solms, and (6) banana corms were collected from the Closed Agriculture Production System (CAPS) Research Station located in Air Duku Village, Rejang Lebong, Bengkulu Province, Indonesia, at elevation of approximately $1.015 \mathrm{~m}$ above sea level $\left(3^{\circ}, 27\right.$ ', 30.38' South Latitude and $102^{\circ}, 36$ ', 51.33' 'East Longitude).

Samples of 100 gram fresh weight of each green biomass were dried at $60{ }^{\circ} \mathrm{C}$ for 48 hours to determine the dry weight content. All dried samples were milled, and then representative samples were stored in tightly corked and labelled bottles for further analysis. The proximate analysis of green biomass nutrients [N-total (\%), P-Bray (\%), K (mg/100 mg), Ca-ex (Me/100 g), Mg-ex (Me/100 g), C (\%), cellulose $(\%)$, lignin $(\%)$ and $\mathrm{C} / \mathrm{N}$ ] was conducted using methods proposed by [22]. Each analysis of leaf nutrient was replicated three times.

All data collected from laboratory analysis were subjected to analysis of variance according to the procedure for complete randomized designs. Means of nutrient contents from individual biomass were compared using Least Significantly Different Test 5\%.

\section{RESULTS AND DISCUSSION}

\section{A. Dry Matter Content}

Laboratory analysis indicated that L. leucocephala (Lamk) had the highest dry matter content (18.3\%), followed by $G$. sepium (Jacq.) Kunth ex Walp. (16.8\%), A. conyzoides L (13.3\%), T. diversifolia (Hemsl.) A. Gray (12.2\%), banana corms $(7.1 \%)$ and E. crassipes (Mart.) Solms (5.2\%). Plant dry matter refers to material remaining after removal of water, and the moisture content reflects the amount of water present in the plant tissues. This portion mainly consists of soluble carbohydrates, such as fructose, sucrose and glucose, and very sensitive to nutrient supplies. With respect to the production of liquid organic fertilizer, dry matter of particular green biomass might determine the effectiveness in formulating the materials used to produce liquid organic fertilizers. Higher dry matter content reduces the total weight of green biomass that should be incorporated in the production of liquid organic fertilizer.

\section{B. N-total}

Nitrogen is very important for plant growth and development, including promoting vegetative growth (leaf and stems), hastening recovery after mowing, production of chlorophyll and other regulating effects in the formation and function of enzymes and protein. According to [23] $\mathrm{N}$ is involved in all of the plant's metabolic processes, its rate of uptake and partition being largely determined by supply and demand during the various stages of plant growth and development.

Results from this experiment indicated that both green biomass of $T$. diversifolia and A. conyzoides had the highest $\mathrm{N}$ content, followed by L. leucocephala, G. sepium, E. crassipes and banana corms (Fig. 1). Each biomass contained N-total of $6.55 \%, 6.55 \%, 5.69 \%, 5.04 \%, 4.17 \%$, and $1.91 \%$, respectively. These figures might be higher than what had been reported elsewhere. Research conducted by [18] reported that green leaf biomass of tithonia content was $3.5 \% \mathrm{~N}$. Other report [20] revealed that $\mathrm{N}$ content of $T$. diversifolia was $2.04 \%$. Meanwhile, nutrient composition of L. leucocephala was reported as much as $0.34 \% \mathrm{~N}$ [24]. Surprisingly, $T$. diversifolia and A. conyzoides had higher $\mathrm{N}$ content than of $L$. leucocephala, legume shrubs that have high $\mathrm{N}$ fixation capability.

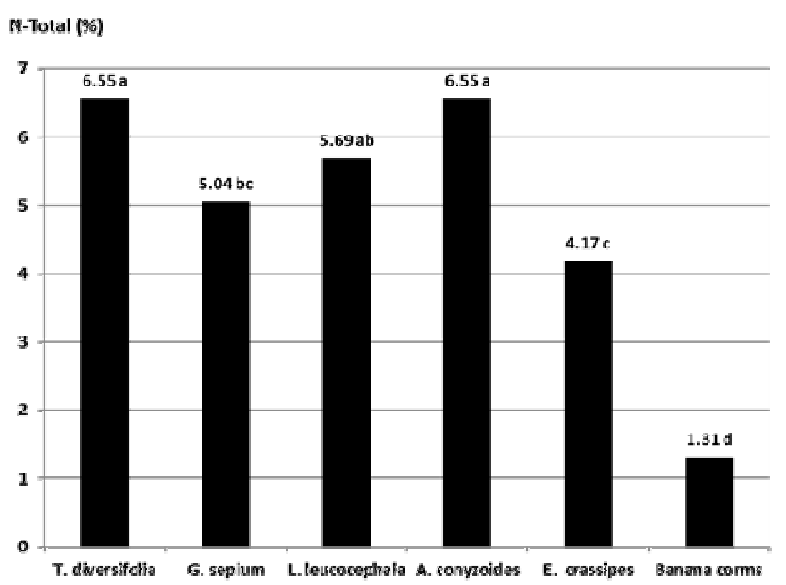

Fig. 1 N-total content of six potential green biomasses. (Means of N-total content followed by the same letter are not significantly different according to Least Significant Difference 5\%)

From $\mathrm{N}$ point of view, $T$. diversifolia and A. conyzoides are recommended to serve as sources of $\mathrm{N}$ for developing liquid organic fertilizer. 


\section{Phosporous Content}

This nutrient stimulates early root formation and growth, strenthens plant aperformance, stimulate flowering, hastens maturity and plays improtant roles in many cell functions. It is very important that liquid organic fertilizer has high $\mathrm{P}$ content to improve crop growth and development. Results from this experiment indicated that $A$. conyzoides was found to have the highest content $(1.71 \%)$, followed by $T$. diversifolia $(0.87 \%)$, G. sepium $(0.33 \%)$, L. leucocephala $(0.32 \%)$, E. Crassipes $(0.32 \%)$ and banana corms $(0.23 \%)$ (Fig. 2). High $\mathrm{P}$ content in G. sepium was comparable to what had been reported by [25] that contained $0.30 \%$ P. In addition, $\mathrm{P}$ content in $T$. diversifolia was higher than that been reported [18] in Western Kenya where tithonia content was $0.37 \% \mathrm{P}$ but lower than what had been reported in Ogbomoso, Nigeria, [20] where $\mathrm{P}$ in Tithonia diversifolia was $1.76 \%$. Meanwhile, nutrient composition of $L$. leucocephala was higher than that of reported by [24] where L. leucocephala had $0.19 \% \mathrm{P}$. This findings suggested that A. conyzoides are recommended to serve as a source of $\mathrm{P}$ for developing liquid organic fertilizer.

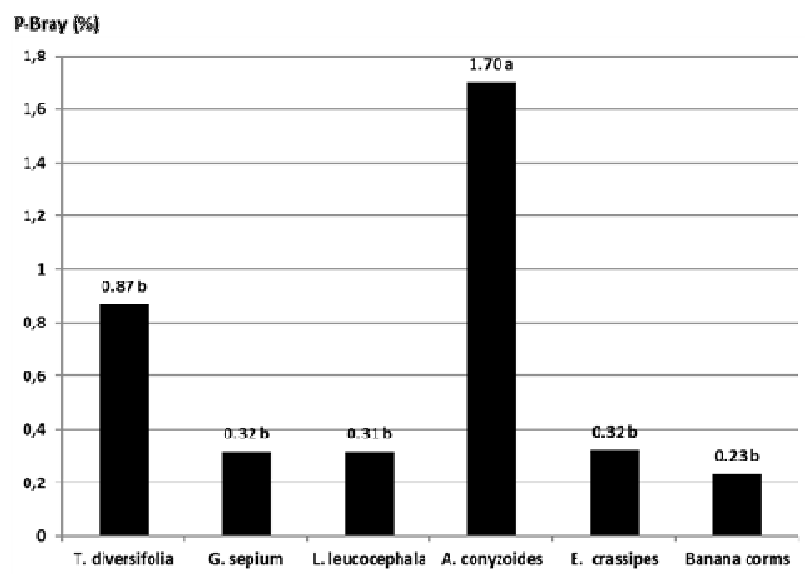

Fig. 2 P-Bray content of six potential green biomasses (Means of P-Bray content followed by the same letter are not significantly different according to Least Significant Difference 5\%)

\section{Potassium Content}

The highest tissue $\mathrm{K}$ content was found in A. conyzoides (8.59 mg/100 mg), followed by G. sepium $(6.21 \mathrm{mg} / 100$ $\mathrm{mg})$, L. leucocephala $(5,98 \mathrm{mg} / 100 \mathrm{mg})$ and E. crassipes, $T$. diversifolia, and banana corms with the amount of $\mathrm{K}$ as much as 4.07, 3.94 and $3.80 \mathrm{mg} / 100 \mathrm{~g}$, respectively (Fig. 3). Although there have been limited reports on $\mathrm{K}$ content in $A$. Conyzoides, this finding revealed that this weed is very promising to serve as a source of $\mathrm{K}$ in formulating liquid organic fertilizer. In addition, the magnitude of $\mathrm{K}$ in $G$. sepium was almost doubling than that of reported by [25] where leaves of $G$. sepium contained about $3.36 \% \mathrm{~K}$. Although it was the lowest compared to other studied green biomass, banana corms contained $3.80 \mathrm{mg} / 100 \mathrm{mg}$ of $\mathrm{K}$. Earlier reference stated that banana plant sap showed a high concentration of potassium in the plant [26].

It appeared that $A$. conyzoides are recommended as a source of $\mathrm{K}$ for developing liquid organic fertilizer. It is very important to have $\mathrm{K}$ in liquid organic fertilizer since $\mathrm{K}$ plays important roles in increasing disease resitance, strengthening cell walls and the quality of many fruit size and quality. Research conducted by [27] reported that K deficiency in organic farming might become a significant problem for successful crop production. It is therefore very important to ensure that liquid organic fertilizer has sufficient $\mathrm{K}$ content.

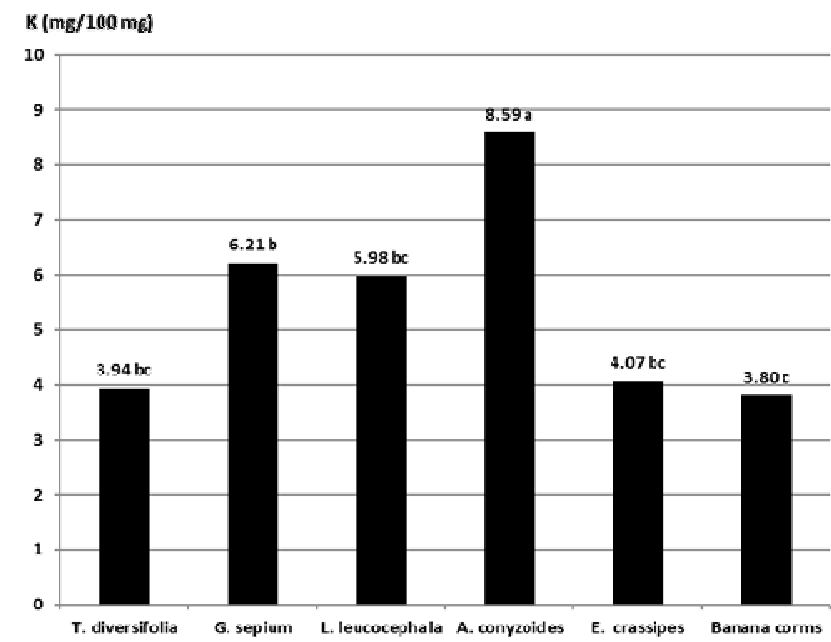

Fig. $3 \mathrm{~K}$ content of six potential green biomasses (Means of $\mathrm{K}$ content followed by the same letter is not significantly different according Least Significant Difference 5\%)

\section{E. Calcium Content (Me/lo0g)}

Calcium is an essential part of cell wall structure. Plant with calcium deficiency might suffered from weakened stems and premature shedding of blossoms and buds. Results indicated that the amount of Ca-ex in leaf tissues of $L$. leucocephala, A. conyzoides, G. sepium and banana corms are relatively similar with the magnitude of $14.50,14.00$, 12.83, and $11.17 \mathrm{Me} / 100 \mathrm{~g}$, respectively (Fig. 4).

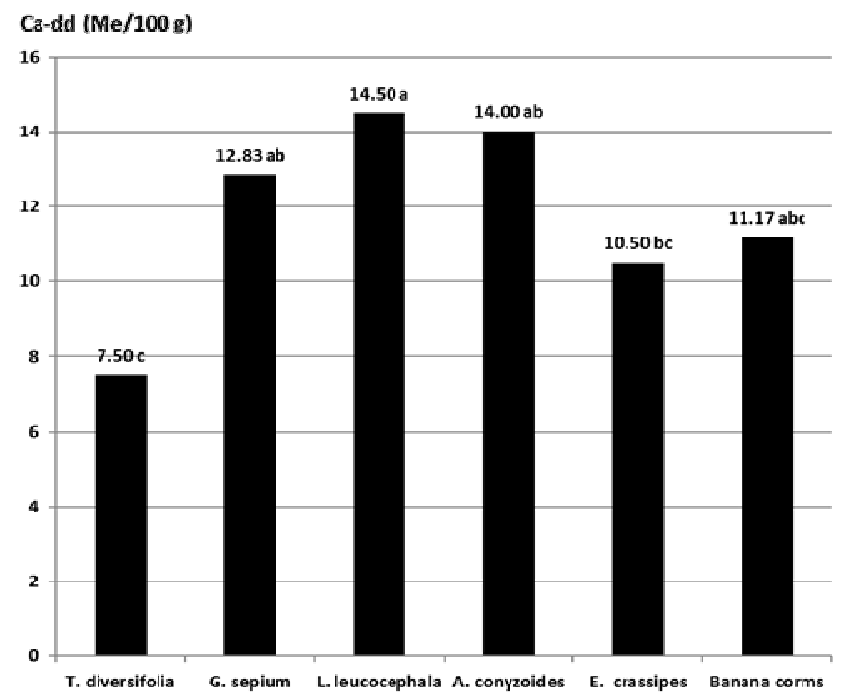

Fig. $4 \mathrm{Ca}$ content of six potential green biomasses (Means of Ca content followed by the same letter is not significantly different according Least Significant Difference 5\%)

The lowest Ca content was noticed in the leaf tissues of T. diversifolia $(7.50 \mathrm{Me} / 100 \mathrm{~g})$, although it was not different with those of in E. Crassipe $(10.50 \mathrm{Me} / 100 \mathrm{~g})$. Ca content in 
G. sepium was much higher than research conducted by [25] where its leaves contained about $0.95 \% \mathrm{Ca}$.

It appeared that both L. leucocephala and A. conyzoides are recommended to serve as sources of calcium for developing liquid organic fertilizer.

\section{F. Magnesium Content (Me/lo0g)}

This nutrient is very essential for maintaining leaf greenness and photosynthesis as well as serves as an activator for many enzymes required in plant growth. The highest tissue Mg-ex content was found in A. conyzoides (12.33 Me/100g), followed by that in leaf tissues of $L$. leucocephala ( $8.50 \mathrm{Me} / 100 \mathrm{~g}$ ) (Fig. 5). In addition, $\mathrm{Mg}$ content in leaf tissues of both G. Sepium $(5,83 \mathrm{Me} / 100 \mathrm{~g})$ and T. diversifolia $(5,67 \mathrm{Me} / 100 \mathrm{~g})$ are similar to that in leaf tissues L. leucocephala. The lowest $\mathrm{Mg}$ content was recorded in the tissues of E.crassipes (4.00 Me/100g) and banana corms $(4.00 \mathrm{Me} / 100 \mathrm{~g})$. This result was higher than the result of research conducted by [25] where leaves of $G$. sepium contained about $0.46 \%$. In addition, research conducted by [20] in Ogbomoso, Nigeria, revealed that $\mathrm{Mg}$ content of $T$. diversifolia was only $0.005 \%$.

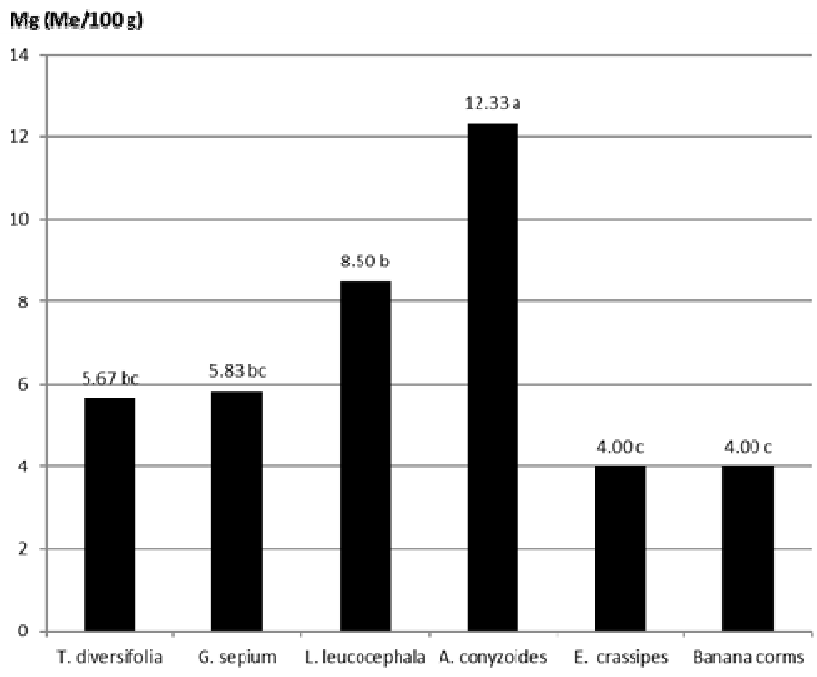

Fig. $5 \mathrm{Mg}$ content of six potential green biomasses (Means of $\mathrm{Mg}$ content followed by the same letter is not significantly different according to Least Significant Difference 5\%)

From $\mathrm{Mg}$ point of view, A. conyzoides is recommended to serve as a source of $\mathrm{Mg}$ for developing liquid organic fertilizer.

\section{G. Carbon Content (\%)}

The highest $\mathrm{C}$ leaf tissue was found in E.crassipes (62.84\%), followed by those in G. sepium (47.74\%) and $L$. leucocephala (46.03\%) and T. diversifolia (40.01\%) (Fig. 6). In addition, the leaf tissues of $A$. conyzoides had lower $\mathrm{C}$ content $(35.42 \%)$, and $\mathrm{C}$ content in banana corms had the lowest $\mathrm{C}$ content among the tested biomasses (13.38\%). The $\mathrm{C}$ content of $T$. diversifolia reported from this finding was much higher than that of reported by [20] where $\mathrm{C}$ content in leaves was recorded as much as $14.00 \%$. In addition, leaf $\mathrm{C}$ contents from this experiment are comparable to a search conducted by [28] indicated that differences in $\mathrm{C}$ content among plant tissues where bark, branch, twig, coarse root, and fine root $\mathrm{C}$ had $37 \%, 76 \%$, $48 \%, 81 \%$, and $63 \%$, respectively.

Carbon is an essential element in plant tissues that readily combines with other elements to make organic compounds that play very important roles in many plant metabolisms. With respect to decomposition rates of green biomass, C content is related to the status $\mathrm{N}$ content in the leaf tissues. Higher ratios of $\mathrm{C}$ to $\mathrm{N}$ decreases the composting rates of green biomass.

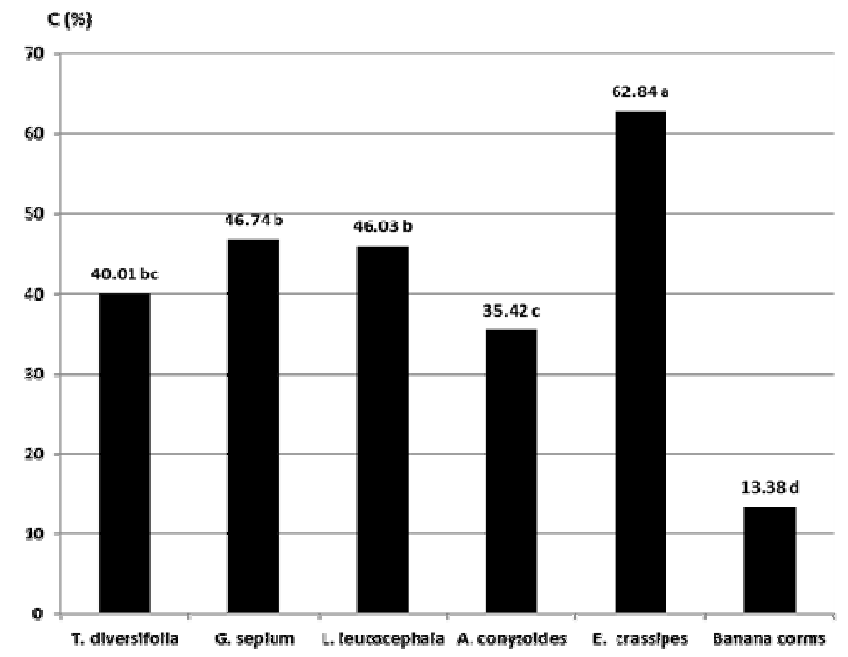

Fig. $6 \mathrm{C}$ content of six potential green biomasses (Means of $\mathrm{C}$ content followed by the same letter is not significantly different according to Least Significant Difference 5\%)

\section{H. Cellulose Content (\%)}

The highest tissue cellulose content was found in $T$. diversifolia $(19.91 \%)$, followed by those in E. crassipes, A. conyzoides and banana corms with the magnitudes of $17.09 \%$, $14.43 \%$, and $14.22 \%$, respectively (Fig.7). Although L. leucocephala had the lowest cellulose content among the tested biomasses $(7,93 \%)$, it was not significantly different with cellulose content in leaf tissues of G. sepium $(11.89 \%)$.

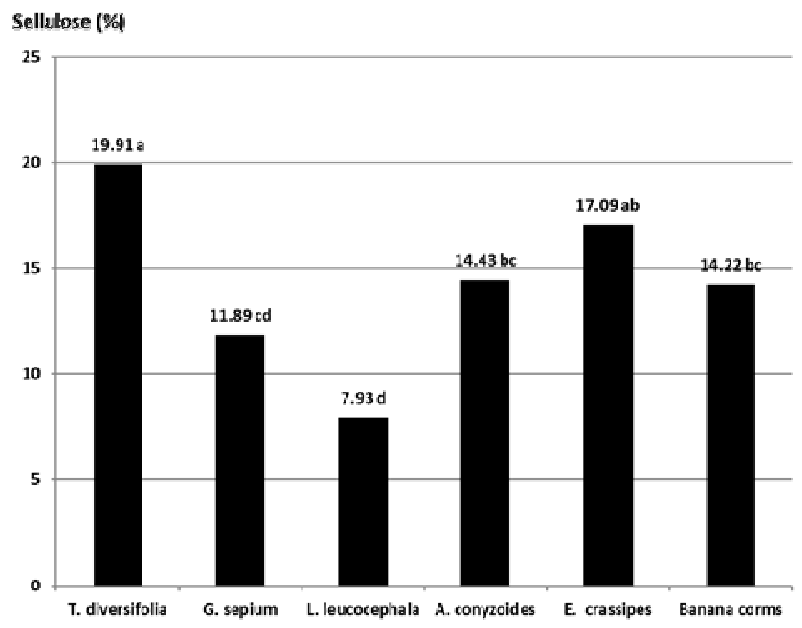

Fig. 7 Cellulose content of six potential green biomasses (Means of cellulose content followed by the same letter are not significantly different according to Least Significant Difference 5\%) 
Cellulose is a very important polysaccharide and a major component of tough cell walls that surround plant cells and makes plant stems, leaves, and branches so strong. Results form this experiment were somehow lower than reported by by [29] where cellulose of wheat straw and switchgrass contained $33-40 \%$ and $30-50 \%$ of the biomass, respectively. It is presumbable that narrow leaves had higher cellulose contents and agroclimatic conditions of these two plants also contributed to such differences.

\section{Lignin Content (\%)}

Lignin content in leaf tissues determines its rate of degradation. All studied biomass had similar lignin content, ranged from 5.90-7.64\% (Fig.8). Lignin content of $T$. diversifolia, $G$. sepium, L. leucocephala, A. conyzoides, E. crassipes and banana corms were $5.96 \%, 6.10 \%, 7.24 \%$, $7.64 \%$, 6.99\%, and $7.27 \%$, respectively. Research conducted by [30] postulated that higher levels of lignin could be responsible for the lower rate of degradation of dry matter. Lignin is an integral cell wall constituent and provides plant strength and resistance to microbial degradation [31]. Lignin contents of studied green biomasses might be considered as low lignin content of biomass. In addition, lignin content of wheat straw and switchgrass were $15-20 \%$ and $5-20 \%$ of the biomass, respectively [29]. This suggests that all studied green biomasses are easily degraded and accepted as materials used in developing liquid organic fertilizer. However, other nutrient contents should be put into higher consideration for using these green biomass as material to develop liquid organic fertilizer.

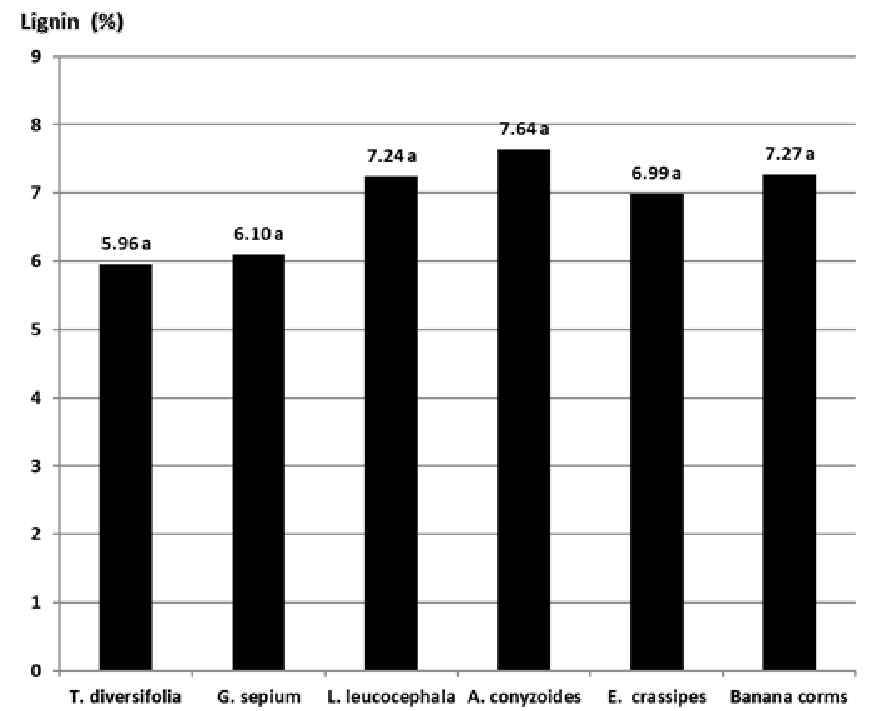

Fig. 8 Lignin content of six potential green biomasses (Means of lignin content followed by the same letter are not significantly different according to Least Significant Difference 5\%)

\section{J. $C / N$}

Results indicated that E.crassipes had the highest $\mathrm{C} / \mathrm{N}$ (15.12) compared to other green biomass (Fig. 9). Meanwhile, G. sepium, L. leucocephala and banana corms had similar $\mathrm{C} / \mathrm{N}$ with the magnitudes of $9.48,8.36$ and 9.80, respectively. The lowest $\mathrm{C} / \mathrm{N}$ were found at $T$. diversifolia
(6.13) and A. conyzoides (5.49). Nevertheless, $\mathrm{C} / \mathrm{N}$ ratios of the evaluated green biomasses were considered to be low, and those materials are very easy to decompose.

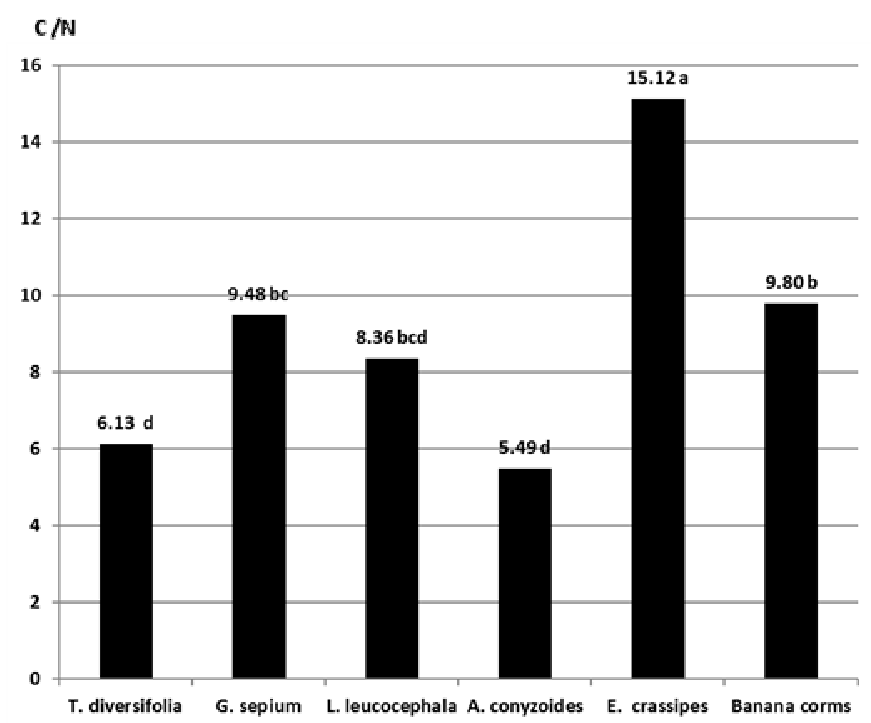

Fig. $9 \mathrm{C} / \mathrm{N}$ content of six potential green biomasses (Means of $\mathrm{C} / \mathrm{N}$ content followed by the same letter is not significantly different accordingn Least Significant Difference 5\%)

According to [32], during the composting, microbial activity utilizes a $\mathrm{C} / \mathrm{N}$ of 30-35. A higher ratio will result in slower composting rates. It is presumable that $\mathrm{C}: \mathrm{N}$ ratios higher than 30 do not provide sufficient nitrogen for optimal growth of the microbial populations and bring about green biomass to remain relatively cool and to degrade slowly. On the other hand, $\mathrm{C}$ to $\mathrm{N}$ ratios lower than 30 allow rapid microbial growth and speedy decomposition of the green biomass.

These results might be different to what had been reported elsewhere since mineral nutrients can vary considerably between plant species or even within a genus [33] and geographical location [34]. In addition, nutrient content of the same plant might be different among locations since the rate of plant growth is determined by its local microclimate conditions. Research conducted by [18] in Western Kenya, for example, revealed green leaf biomass of tithonia content were $3.5 \% \mathrm{~N}, 0.37 \% \mathrm{P}$ and $4.1 \% \mathrm{~K}$ on a dry matter basis. In Ogbomoso, Nigeria, [20] reported that chemical properties $\mathrm{N}, \mathrm{P}, \mathrm{K}, \mathrm{Ca}, \mathrm{Mg}, \mathrm{C}$ and $\mathrm{C} / \mathrm{N}$ in Tithonia diversifolia were $24.04 \%, 1.76 \%, 0.82 \%, 3.92 \%, 3.07 \%, 0.005 \%, 14.00 \%$ and $8: 1$, respectively.

Plant species did make different in terms of nutrient contents. Research conducted by [35] indicated that shrub of Abeokuta, Nigeria, Caesalpinia pulcherrima, contained, P, $\mathrm{K}, \mathrm{Ca}$ and $\mathrm{Mg}$ as much as $0.17 \%, 0.48 \%, 1.19 \%$ and $0.23 \%$, respectively (dry weight basis). Meanwhile, $\mathrm{P}, \mathrm{K}, \mathrm{Ca}$ and $\mathrm{Mg}$ content in Cassia mimosoides were $0.07 \%, 0.35 \%$, $0.54 \%$ and $0.09 \%$, respectively. In addition, the species of Desmodium velutinum contained $0.05 \%, 0.17 \%, 0.85 \%$ and $0.08 \%$ of $\mathrm{P}, \mathrm{K}, \mathrm{Ca}$ and $\mathrm{Mg}$, respectively. A shrub of Flemingia macrophylla had $0.02 \%, 1.35 \%, 0.06 \%$ and $0.16 \%$ of $\mathrm{P}, \mathrm{K}, \mathrm{Ca}$ and $\mathrm{Mg}$, respectively. Tephrosia bracteolata contained $0.04 \%, 0.14 \%, 0.88 \%$ and $0.19 \%$ of $\mathrm{P}$, $\mathrm{K}, \mathrm{Ca}$ and $\mathrm{Mg}$, respectively, while Tephrosia densiflora had 
$0.04 \%, 0.18 \%, 2.08 \%$ and $0.45 \%$ of $\mathrm{P}, \mathrm{K}, \mathrm{Ca}$ and $\mathrm{Mg}$, respectively. Such high nutrient values present in the leaf tissues influence the nutrient contents of produced organic fertilizer, including compost (solid organic fertilizer). The magnitude of compost nutrients is also determined by the mode of the biomass application during the composting process. According to [36] gradual application of green biomass, Tithonia diversifolia (Hemsl.) A. Gray and Leucaena leucocephala (Lamk.), during composting of crop residue produced a better quality of compost which eventually improves crop growth and development.

Results from this experiment (Figs. 1-9) provide worth information for developing liquid organic fertilizer that suitable for closed agriculture production systems in the highland of Bengkulu. It was clear that none of six green biomasses tested in this experiment provided complete high nutrient content. Each biomass has superiority over other biomasses in particular nutrient. It is therefore suggested that the use of green biomass for production of liquid organic fertilizer could not rely on single biomass. The source of green biomass should be a combination of several green biomasses in order to produce liquid organic fertilizer with high $\mathrm{N}, \mathrm{P}, \mathrm{K}, \mathrm{Ca}$, and $\mathrm{Mg}$ content. In addition, it also important to mixture the green biomasses with other natural composting material, such as poor soil [36], wood ash [37], cow manure [12], [13], [14], [38] in order to increase composting rates, nutrient quality and crop yields. The use of a single green biomass for liquid organic fertilizer might provide high particular nutrient content, but low in other nutrients. This was confirmed by our previous result [12], [13], [14] where tithonia-enriched liquid organic fertilizer contained 3,36\% N, $146 \mathrm{ppm} \mathrm{P}$, and $0.033 \% \mathrm{~K}$. Although nitrogen content of this liquid organic fertilizer somehow comply with the standard quality for organic fertilizer issued by Indonesian Standardization Board (SNI 19-7030-2004) where total $\mathrm{N}$ should be $>0.4 \%$, but $\mathrm{P}$ and $\mathrm{K}$ content were very much lower than standard (SNI-19-7030-2004) which must be above $0.10 \%\left(\mathrm{P}_{2} \mathrm{O}_{5}\right)$ and $0.20 \%\left(\mathrm{~K}_{2} \mathrm{O}\right)$, respectively.

\section{CONCLUSIONS}

This experiment concluded that there was no single green biomass that has all high-nutrient contents. However, A. conyzoides is the most promising green biomass for production of liquid organic fertilizer compared to others, followed by $T$. diversifolia and G. sepium. Both $T$. diversifolia and A. conyzoides are promising sources for $\mathrm{N}$ and P. Sources of K are A. conyzoides and G. Sepium. In addition, L. Leucocephala and A. conyzoides are sources of $\mathrm{Ca}$ and $\mathrm{Mg}$ nutrients. The highest $\mathrm{C}$ content was found in E.crassipes, followed by G. Sepium. T. diversifolia had the highest cellulose content, followed by E.crassipes. Lignin content of all biomasses was similar, ranged from $5.96 \%$ to $7.45 \%$. Lastly, $\mathrm{C} / \mathrm{N}$ ratios of all studied green biomass were less than 16 (ranged from 5.49 to 15.12 ). To produce liquid organic fertilizer with high $\mathrm{N}, \mathrm{P}, \mathrm{K}, \mathrm{Ca}$ and $\mathrm{Mg}$ content, several green biomasses should be properly combined.

\section{ACKNOWLEDGEMENT}

Sincerely thank Ministry of Research, Technology and Higher Education, Indonesia for financing this project through 2016 Fundamental Research Scheme.

\section{REFERENCES}

[1] Brust, G., D. S. Egel, and E.T. Maynard. Organic Vegetable Production. Purdue University Cooperative Extension Service. Bulletin. \# 316. 2003.

[2] H.D. Foth and B.G. Ellis, B. G. Soil Fertility. $2^{\text {nd }}$ Ed. Lewis Pub. Tokyo. 316 pages. 1997.

[3] T.K. Hartz, J.P. Mitchell and C. Giannini. Nitrogen and carbon mineralization dynamics of manures and composts. HortScience. vol. 35. pp.209-212. 2000.

[4] Amanullah, K.M. Kakar, A. Khan, I. Khan, Z. Shah and Z. Hussain. Growth and yield response of maize (Zea mays L.) to foliar NPKfertilizers under moisture stress condition. Soil Environment. vol. 33. pp.116-123. 2014.

[5] N. Darmayanti, N. Marlina, E. Hawayanti. Pengaruh Jenis Pupuk Organik Cair dan Takaran Pupuk Organik Plus terhadap Pertumbuhan dan Produksi Tanaman Selada (Lactuca sativa L.) pada Sistem Budidaya Vertikultur. Klorofil. vol. 7. pp. 77-80. 2012

[6] F. J. Nasution, L. Mawarni, Meiriani. Aplikasi Pupuk Organik Padat dan Cair dari Kulit Pisang Kepok untuk Pertumbuhan dan Produksi Sawi (Brassica juncea L.). Program Studi Agroekoteknologi Fakultas Pertanian, USU. Medan. Online Agroekoteknologi. vol. 1. pp. 10291037. 2014.

[7] L. Gomies, H. Rehatta J. Nandissa. Pengaruh Pupuk Organik Cair RI1 terhadap Pertumbuhan dan Produksi Tanaman Kubis Bunga (Brassica oleracea Var. Botrytis L.). Agrologia. vol. 1. pp. 13-20. 2012.

[8] P. Sinaga, Meiriani Y. Hasanah. Respons Pertumbuhan dan Produksi Kailan (Brassica oleraceae L.) pada Pemberian Berbagai Dosis Pupuk Organik Cair Paitan (Tithonia diversifolia Hemsl.) Gray) Program Studi Agroekoteknologi, Fakultas Pertanian, USU, Medan. Online Agroekoteknologi. vol. 2. pp. 584-588. 2014.

[9] S. Parman. Pengaruh Pemberian Pupuk Organik Cair terhadap Pertumbuhan dan Produksi Kentang (Solanum tuberosum L.). Buletin Anatomi dan Fisiologi. vol. 15. pp. 21-31. 2007.

[10] Z. Zhai, D.L. Ehret, T. Forge, W. Lin, M. Dorais, and P.A. Papadopoulos. Organic Fertilizers For Greenhouse Tomatoes : Productivity and Substrate Microbiology. HortScience. vol. 44. pp. 800-809. 2009.

[11] M. S. Pasaribu, W.A. Barus, H. Kurnianto.. Pengaruh Konsentrasi Dan Interval Waktu Pemberian Pupuk Organik Cair (POC) NASA Terhadap Pertumbuhan dan Produksi Jagung Manis (Zea Mays Saccharata Sturt). Agrium . vol. 17. pp. 46-52. 2011.

[12] Fahrurrozi, Z. Muktamar, N. Setyowati, S. Sudjatmiko, M. Chozin. Evaluation of Tithonia-enriched Liquid Organic Fertilizer for Organic Carrot Production. Journal Agricultural Technology. vol. 11 pp. 1705-1712. 2015.

[13] Fahrurrozi, Z. Muktamar, Dwatmadji, N. Setyowati, S. Sudjatmiko, M. Chozin. Growth and Yield Responses of Three Sweet Corn (Zea mays L. var. Saccharata) Varieties to Local-based Liquid Organic Fertilizer. International Journal Advanced Science. Engineering, Information Technology. vol. 6. pp. 319-323. 2016.

[14] Muktamar, Z, Fahrurrozi, Dwatmadji, N. Setyowati, S. Sudjatmiko, M. Chozin. Selected Macronutrient Uptake by Sweet Corn under Different Rates of Liquid Organic Fertilizer in Closed Agriculture System. International Journal Advanced Science, Engineering, Information Technology. vol. 6. pp. 258-261. 2016.

[15] D. Haytova. A Review of Roliar Fertilization of Some Vegetable Crops. Annual Review and Research in Biology. vol. 3. pp. 455-465. 2013.

[16] G. Ranalli, Botturea G, Taddei P, Garavni M, Marchetti R, Sorlini G. Composting of solid and sludge residues from agricultural and food industries. Bioindicators of monitoring and compost maturity. J. Environ. Sci. Health. vol. 36. pp. 415-436. 2001.

[17] P. Drechsel, B., Reck, Composted shrub-prunings and other organic manures for smallholder farming systems in southern Rwanda. Agroforestry Systems. vol. 39. pp. 1-12. 1998.

[18] B.C.A., Jama, R.J. Buresh, A. Niamg, C.N. Gachenco, G. Nziguheba, B. Amadalo. Tithonia diversifolia as green manure for 
soil fertility improvement in Western Kenya. Review Agroforestry Systems. vol. 4. pp. 201-221. 2000.

[19] G. R. Nziguheba, P. Merckx, C.A. Mutuo. Combining Tithonia diversifolia and fertilizers for maize production in a phosphorus deficient soil in Kenya. Agroforestry Systems. vol. 55. pp. 165-174. 2002

[20] O.S. Olabode, O. Sola, W.B. Akanbi, G.O. Adesina, G.O. P.A. Babajide. Evaluation of Tithonia diversifolia (Hemsl.) A Gray for soil improvement. World Journal of Agricultural Science. vol. 3. pp. 503-507. 2007.

[21] M. Jacob, K. Viendenz, A. Pole, F.M. Thomas. Leaf litter decomposition in temperate deciduous forest stands with a decreasing fraction of beech (Fagus sylvatica). Oecologia. vol. 164. pp. 1083-1094. 2010.

[22] S. Yoshida, D.A. Forno, J.H. Cook, K.A. Gomez. Laboratory Manual for Physiological Studies of Rice. IRRI, Los Banos. Philippines. 83p. 1976.

[23] G. Delogua, L. Cattivelli, N. Pecchioni, D. De Falcis, T. Maggiore, A.M. Stanca. Uptake and agronomic efficiency of nitrogen in winter barley and winter wheat. European Journal of Agronomy. vol. 9. pp. 11-20. 1998.

[24] D.A. Alabi, A.A. Alausa. Evaluation of the Mineral Nutrients and Organic Food Contents of the Seeds of Lablab purpureus, Leucaena leucocephala and Mucuna utilis for Domestic Consumption and Industrial Utilization. World Journal of Agricultural Sciences. vol. 2. pp. 115-118. 2006.

[25] C.F.I. Onwuka. Gliricidia sepium as dry season feed for goat production in Nigeria. In : Proceeding Workshop of Potentials of forage legumes in farming systems of sub-Saharan Africa. Ethiopia: International Livestock Centre for Africa (ILCA). pp. 533-539. 1985

[26] S. Sathiamoorthy, K.J. Jeyabaskaran. Potassium management of banana. IPI/NARCTT Regional Workshop: Potassium and Water Management in West Asia and North Africa, Amman (JOR). pp. 499-516. 2001.

[27] M. Askegaard, J. Eriksen Residual effect and leaching of $\mathrm{N}$ and $\mathrm{K}$ in cropping systems with clover and ryegrass catch crops on a coarse sand. Agriculture, Ecosystems and Environment. vol. 123. pp. 99108. 2008.
[28] Thomas, S.C. A.R. Martin. Carbon Content of Tree Tissues: A Synthesis. Forests. vol. 3. pp. 332-352. 2012

[29] P. McKendry. Energy production from biomass (part 1): overview of biomass. Bioresoure Tecchnology. vol. 83. pp. 37-46. 2002.

[30] C.M. Ferri, N.P. Stritzler, J.H. Pagella. Nitrogen fertilization on rye pasture: effect on forage chemical composition, voluntary intake, digestibility and rumen degradation. J. Agron. Crop Sci. vol. 190. pp. 347-354. 2004.

[31] D.S. Argyropoulos, S.B. Menachem. Lignin. In: K.E.L. Eriksson, (Ed.), Advances in Biochemical Engineering Biotechnology. Springer, Germany. vol. 57. pp. 127-158. 1997.

[32] F.G. Prahl, J. R. Ertel, M. A. Goni, M. A. Sparrow, B. Eversmeyer Terrestrial Organic-Carbon Contributions to Sediments on the Washington Margin. Geochimica Et Cosmochimica Acta. vol. 58. pp. 3035-3048. 1994

[33] T. D. Landis, D. L. Haase, R. K. Dumroese. Plant Nutrient Testing and Analysis in Forest and Conservation Nurseries. USDA Forest Service Proceedings RMRS-P-35. pp. 75-83. 2005.

[34] G. Bauer, E.D. Schulze, M. Mund. Nutrient contents and concentrations in relation to growth of Picea abies and Fagus sylvatica along a European transect. Tree Physiology. vol. 17. pp. 777-786. 1997.

[35] O.O. Oduguwa, C.O.N. Ikeobi, B.A. Oduguwai, O.O. Oyedele. Chemical Evaluation of Foliage of some Tropical Leguminous Trees and Shrubs as Fodder. Pertanika. Journal of Tropical Agricultural Science. vol. 20. pp. 31-34. 1997.

[36] L.G. Taguiling. Quality Improvement of Organic Compost Using Green Biomass. European Scientific Journal. vol. 9. pp. 319-341. 2013.

[37] L.G. Taguiling. Effect of Green Biomasses on Compost Quality. International Journal of Scientific and Research Publications. vol. 6 pp. 509-513. 2016.

[38] M. Simarmata, L. Susanti and N. Setyowati. Utilization of manure and green organic composts as alternative fertilizers for cauliflower production. Journal of Agricultural Technology. vol.12. pp. 311-319. 2016 